Bangladesh J. Bot. 48(1): 85-93, 2019 (March)

\title{
COMBINING ABILITY ANALYSIS IN BREAD WHEAT (TRITICUM AESTIVUM (L.) EM. THELL) UNDER DIFFERENT ENVIRONMENTAL CONDITIONS
}

\author{
Vijay Sharma*, NS Dodiya ${ }^{1}$, RB Dubey ${ }^{1}$ and Rumana Khan ${ }^{1}$ \\ Department of Genetics and Plant Breeding, \\ Banda University of Agriculture and Technology, Banda-210001, India
}

Keywords: Combining ability, Bread wheat, Diallel analysis, GCA, SCA

\begin{abstract}
Pooled analysis of 8 genotypes of wheat of diverse origin, their $28 \mathrm{~F}_{1} \mathrm{~s}$ and 2 checks was carried out in 4 different environments to study the combining ability in bread wheat for grain yield and its component traits. On pooled basis, analysis of variance due to GCA and SCA was significant for all characters revealed difference between parents for GCA and difference between crosses for SCA. Similarly, mean square due to GCA $\times \mathrm{E}$ was significant for number of effective tillers per plant and flag leaf area revealed influence of environment on GCA. Whereas SCA $\times \mathrm{E}$ was also significant for number of effective tillers per plant and grain yield per plant revealed influence of environment on SCA. The variance due to GCA was higher than their respective SCA for all characters except number of grains per spike indicating that additive type of gene action played role in the expression of all these traits. Significant GCA effects for grain yield and its component traits were exhibited by the parents HD 2987, Lok 1 and HI 1544. Fourteen crosses recorded showed significant SCA effects for grain yield and related traits.
\end{abstract}

\section{Introduction}

Bread wheat $(2 \mathrm{n}=6 \mathrm{x}=42)$ an annual self-pollinated crop belonging to Poaceae family and Triticum genus is most widely consumed cereal crop in India where it meets the basic food requirements of human population. It is popularly known as 'Stuff of life or King of the cereals' because of the acreage occupied, high productivity and the prominent position it holds in the international food grain trade. It is grown in temperate, irrigated to dry and high-rainfall areas and in warm, humid to dry, cold environments. In India, area and production of wheat during year 2015 2016 were recorded 30.22 million ha and 93.50 million tonnes respectively with an average productivity of $3093 \mathrm{~kg} / \mathrm{ha}$ (DAC \& FW 2016).

Wheat is a thermo sensitive crop mostly grown in temperate environment. However, it is predominantly consumed in tropical and subtropical regions of the world. In subtropical regions it is cultivated in winter season, but it exposed to high temperature stress at the end of the season i.e. at grain filling stage. Exposure to higher temperature $\left(>35^{\circ} \mathrm{C}\right)$ or heat stress during the grain-filling period reduces the yield and decreases quality. Generation of information on the effect of high temperature stress on various traits may be helpful for developing thermo-tolerance wheat variety. Hence, now breeding for heat tolerance has become an integral component of wheat improvement. For further progress, knowledge of breeding behavior, particularly of combining ability and type of gene action for the various traits is necessary. The estimates of combining ability variances and effects provide useful information regarding the selection of suitable parents for effective hybridization programme and at the same time elucidates the nature and magnitude of different types of gene action. Since, the nature of gene action with genetic architecture of population involved in

*Author for correspondence: <107vijaysharma@gmail.com>. 'Department of Genetics and Plant Breeding, Maharana Pratap University of Agriculture and Technology, Udaipur- 313001, India. 
hybridization, it is necessary to evaluate the parents for their combining ability. This information enables the breeder to evaluate and classify selected parental material for their utility in development of high yielding $F_{1}$ hybrids in wheat.

According to Braun et al. (1996), large scale testing and crossing programmes using diverse gene pool will most likely have high chances of identifying widely adapted germplasm, break genetic linkage and pyramid desired genes that testing in a narrow environmental range restricts genetic diversity in the crossing programmes. Ceccarelli (1989) suggested that environments used to test breeding material often differ widely in their effect on crop yield. By exposing a number of genotypes in a set of contrasting environments, it is possible to identify genotypes with high average yield and low $\mathrm{G} \times \mathrm{E}$ interaction.

Keeping the above fact in mind, the present investigation was carried out predict the performance of these varieties in hybrid combinations for components of grain yield and heat tolerance under four different environments through half diallel crosses and to evaluate the type of gene action involved in yield and its contributing traits.

\section{Materials and Methods}

Experimental materials consisting of 8 diverse genotypes (Table 1) selected on the basis of broad range of genetic diversity for major yield components, geographical origin, heat tolerance and their suitability for different yield traits, were crossed in half diallel fashion resulting in $28 \mathrm{~F}_{1} \mathrm{~S}$ at Research Farm, Rajasthan College of Agriculture, Udaipur (Rajasthan) during the year 2014-15. These 8 parents and their $28 \mathrm{~F}_{1} \mathrm{~s}$ were grown in a randomized block design with 3 replications under early sown $\left(E_{1}\right)$, normal sown $\left(E_{2}\right)$, late sown $\left(E_{3}\right)$ and very late sown $\left(E_{4}\right)$ conditions. The environments were created by four different date of sowings (Table 2). Row-to-row and plant-toplant distances were 30 and $10 \mathrm{~cm}$, respectively in each environment. Recommended plant protection procedures were followed for raising the crop in all the environments.

Table 1. Particulars of wheat parent materials used.

\begin{tabular}{cll}
\hline Sl. No. & Name of cultivar & Pedigree \\
\hline 1. & HD 2932(PUSA WHEAT 111) & KAUZ/STAR//HD 2643 \\
2. & GW 366 & DL 802-3/GW 232 \\
3. & Raj 4037 & DL 788-2 / RAJ 3717 \\
4. & PBW 175 & HD 2160/WG 1025 \\
5. & HI 1544 (PURNA) & HINDI 62/BOBWHITE/ CPAN 2099 \\
6. & Raj 4079 & UP 2363/WH 595 \\
7. & HD 2987(PUSA BAHAR) & HI1011/HD2348//MENDOS//IWP 72/DL 153-2 \\
8. & LOK 1 & S-308 / S 331 \\
\hline
\end{tabular}

Table 2. The detail of the four environments created.

\begin{tabular}{ll}
\hline Environment & Date of sowing \\
\hline $\mathrm{E}_{1}$ (Early sown) & October 27, 2015 \\
$\mathrm{E}_{2}$ (Normal sown) & November 17, 2015 \\
$\mathrm{E}_{3}$ (Late sown) & December 07, 2015 \\
$\mathrm{E}_{4}$ (Very late sown) & December 27, 2015 \\
\hline
\end{tabular}


The observation was recorded on five randomly selected competitive plants from each plot in each replication in case of parents, $F_{1} s$ and checks in all the four environments separately on 11 distinct morphological characters, except days to $50 \%$ flowering and days to maturity, where it was observed on complete plot basis. The data on days to heading, days to maturity, plant height, number of effective tillers per plant, spike length, number of grains per spike, flag leaf area, 1000 grain weight, biological yield per plant, grain yield per plant and harvest index were recorded for statistical analysis.

The mean value of the recorded observation was subjected to analysis of variance (ANOVA) using the standard procedures of Panse and Sukhatme (1985). Combining ability analysis was done by using Griffing's (1956) Method II (parents and one set of $F_{1} s$ without reciprocals), Model I (fixed effect), and pooled analysis over environments was done according to method suggested by Singh (1973).

\section{Results and Discussion}

A pooled analysis over environments was computed to obtain less biased estimates of the various types of variances and their interactions with the environments is presented in Table 3. The variances for GCA and SCA were highly significant for all the characters revealed difference between parents for GCA and difference between crosses for SCA. Variance for GCA $\times$ E significant for number of effective tillers per plant and flag leaf area revealed influence of environment on GCA. Similarly, SCA $\times$ E was significant for number of effective tillers per plant and grain yield per plant revealed influence of environment on SCA. Variance for GCA was higher than their respective SCA variance for all the characters except number of grains per spike indicating additive type of gene action played role in the expression of all these traits. Similar finding has been reported by Joshi et al. 2002, Sharma et al. 2003, Singh and Yadav 2011.

Table 3. Combining ability mean square and error mean square over the environments for different characters.

\begin{tabular}{|c|c|c|c|c|c|c|c|c|c|}
\hline \multirow{3}{*}{$\begin{array}{l}\text { S1. } \\
\text { No. }\end{array}$} & \multirow{3}{*}{ Characters } & \multicolumn{8}{|c|}{ Source } \\
\hline & & \multirow{2}{*}{$\begin{array}{l}\text { Env } \\
{[3]}\end{array}$} & \multirow{2}{*}{$\begin{array}{l}\text { GCA } \\
{[7]}\end{array}$} & \multirow{2}{*}{$\begin{array}{l}\text { SCA } \\
{[28]}\end{array}$} & \multicolumn{2}{|c|}{$\mathrm{GCA} \times \mathrm{E} \mathrm{SCA} \times \mathrm{E}$} & \multirow{2}{*}{$\begin{array}{l}\begin{array}{l}\text { Pooled } \\
\text { Error }\end{array} \\
{[280]}\end{array}$} & \multirow[t]{2}{*}{$\begin{array}{l}\text { GCA } \\
\text { Variance }\end{array}$} & \multirow[t]{2}{*}{$\begin{array}{l}\text { SCA } \\
\text { Variance }\end{array}$} \\
\hline & & & & & [21] & [84] & & & \\
\hline 1 & Days to flowering & $26.10^{* * *}$ & $27.95^{* *}$ & $8.19 * *$ & 0.49 & 0.66 & 1.23 & 2.07 & 4.68 \\
\hline 2 & Days to maturity & $298.43 * *$ & $12.29 * *$ & $7.29 * *$ & 2.65 & 1.79 & 2.05 & 24.70 & 1.79 \\
\hline 3 & Plant height & $269.37 * *$ & $108.27 * *$ & $17.09 * *$ & 2.75 & 2.24 & 4.70 & 22.06 & 18.13 \\
\hline 4 & No. of effective tillers per plant & $10.82 * *$ & $4.47 * *$ & $5.74 * *$ & 0.39 & 0.23 & 0.27 & 0.88 & 0.73 \\
\hline 5 & Spike length & $4.52 * *$ & $3.36 * *$ & $3.20 * *$ & 0.11 & 0.07 & 0.43 & 0.34 & 0.51 \\
\hline 6 & No. of grains per spike & $15.18 *$ & $31.13 * *$ & $39.77 * *$ & 0.45 & 0.56 & 4.81 & 0.86 & 22.10 \\
\hline 7 & Flag leaf area & $8.80 * *$ & $40.23 * *$ & $41.70 * *$ & 0.48 & 0.27 & 1.32 & 0.62 & 6.81 \\
\hline 8 & 1000 grain weight $(\mathrm{g})$ & $27.88 * *$ & $7.45^{* *}$ & $25.65 * *$ & 0.16 & 0.25 & 0.85 & 2.25 & 1.15 \\
\hline 9 & Biological yield per plant & $404.11 * *$ & $168.68 * *$ & $172.59 * *$ & 3.45 & 1.61 & 6.71 & 33.12 & 28.34 \\
\hline 10 & Grain yield per plant & $85.82 * *$ & $13.56^{* * *}$ & $22.28 * *$ & 0.65 & 0.52 & 0.76 & 7.09 & 2.24 \\
\hline 11 & Harvest index & $17.08 *$ & $19.49 * *$ & $14.16^{* * *}$ & 4.72 & 3.47 & 4.53 & 1.05 & 2.62 \\
\hline
\end{tabular}

*,** Significant at 5 and 1 per cent, respectively (Model I).

The estimate of general combining ability effects of the parents for 11 characters for individual and pooled environments is presented in Tables 4, 5, 6 and 7. 


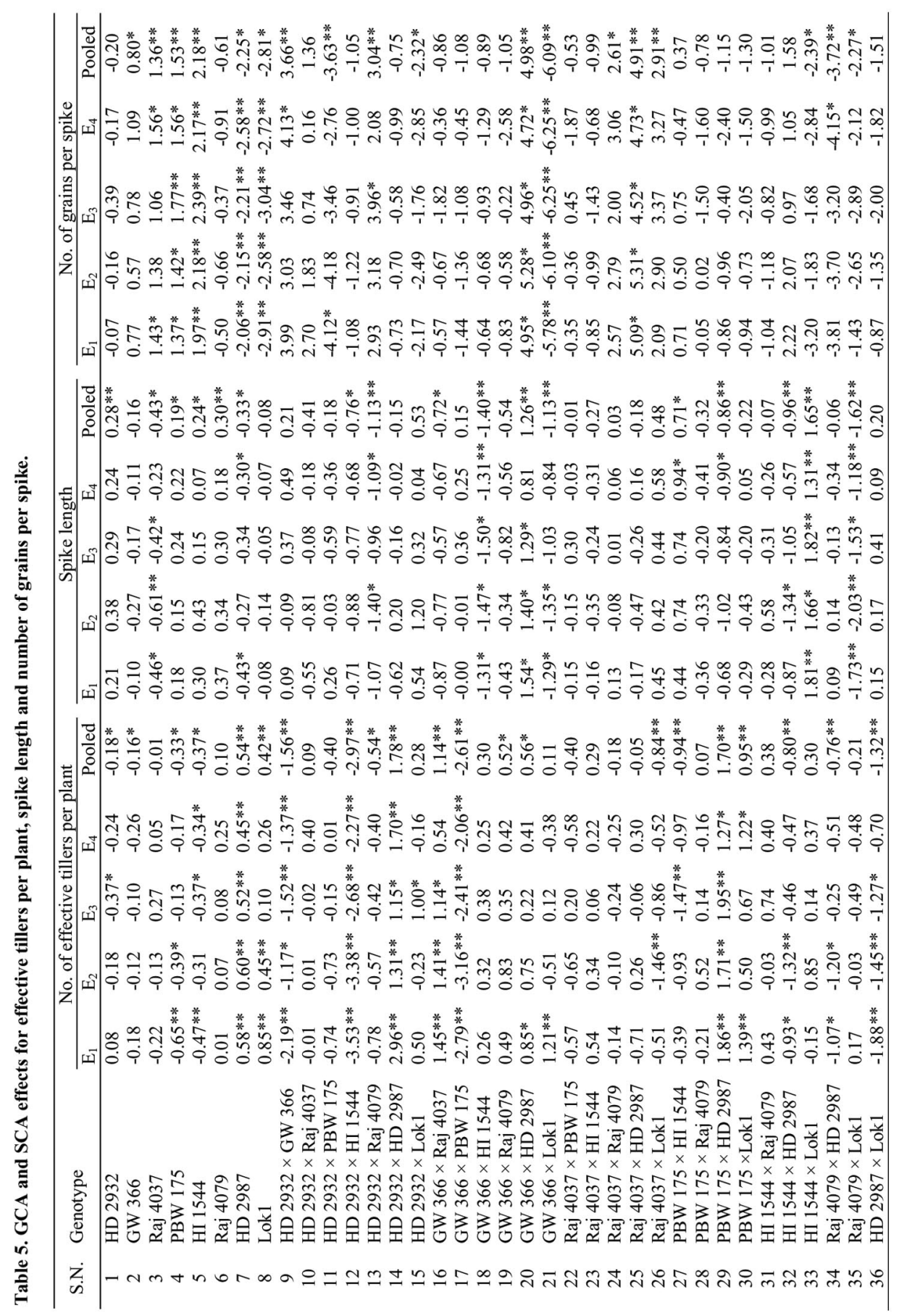




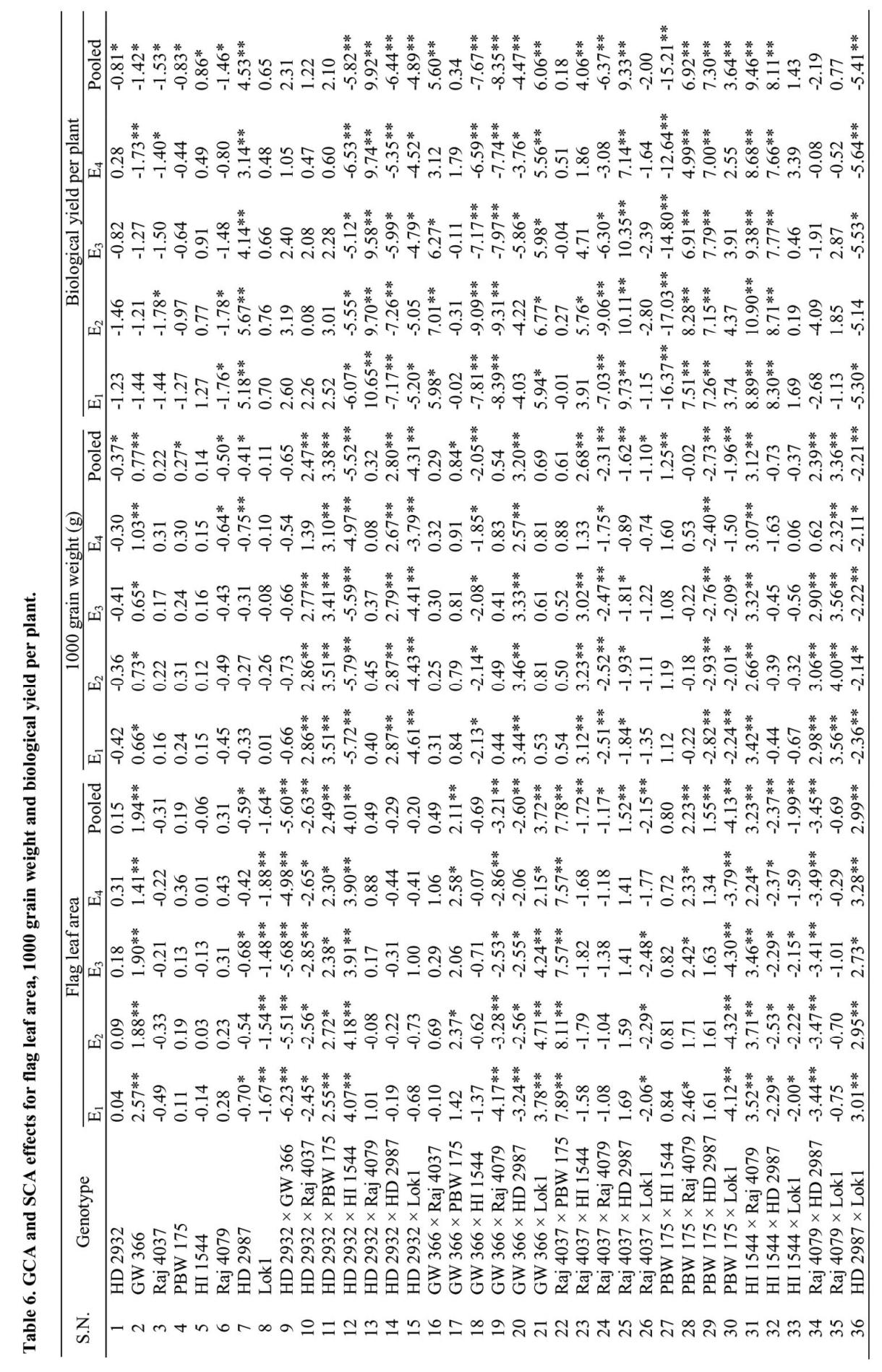




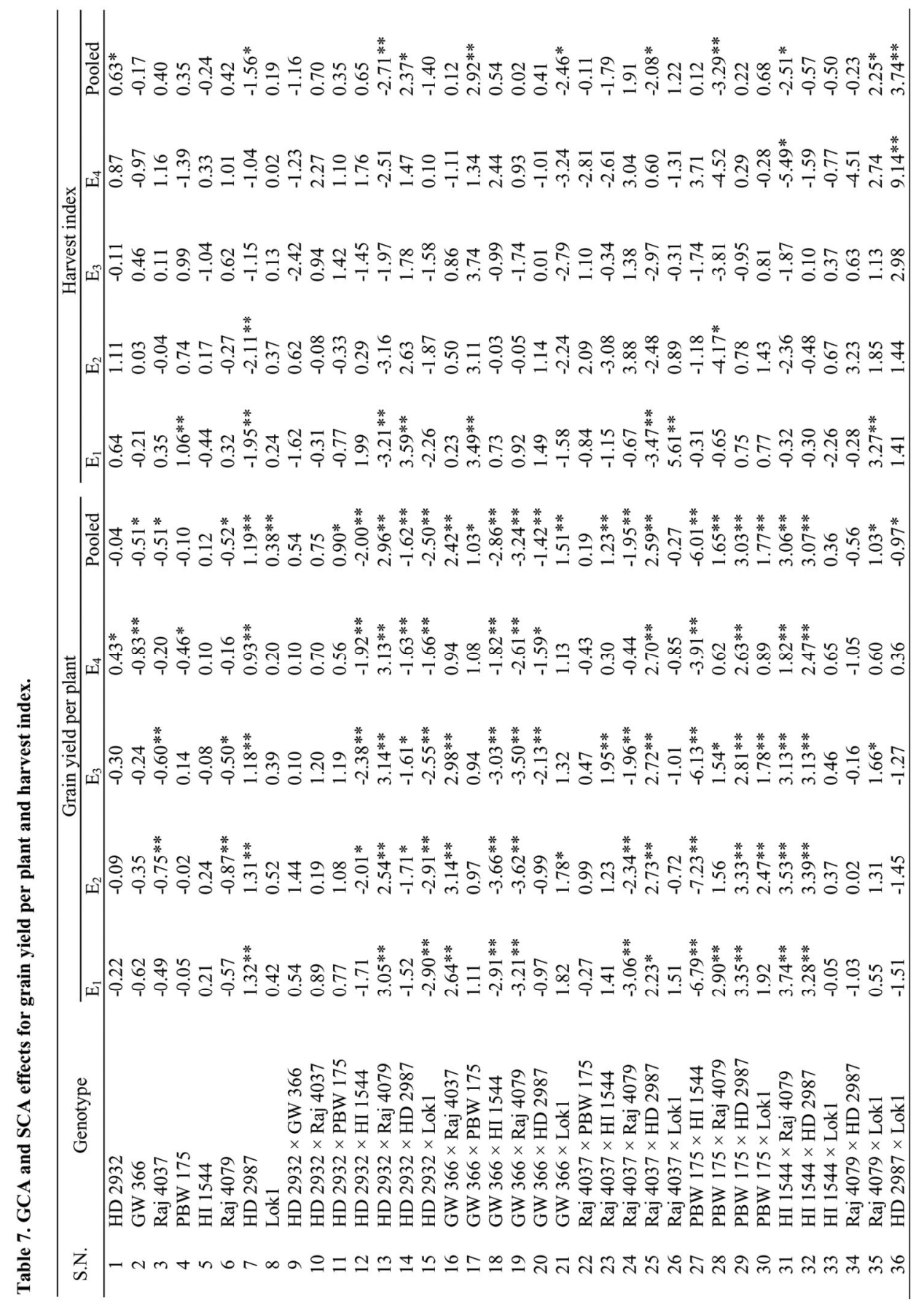


General combining effect revealed that Raj 4037 in $E_{1}$ and in pooled and Lok 1 in remaining three environments showed highest GCA effect for days to heading. For days to maturity, Lok 1 in $\mathrm{E}_{3}$ and in pooled was the good general combiner. None of the parents had significant GCA effects in $E_{1}, E_{2}$ and $E_{4}$ for early maturity. Parent Raj 4079 for plant height, HI 1544 for number of grains per spike, HD 2987 for biological yield per plant and grain yield per plant was the consistently good general combiner in all the four environments including pooled. Highest GCA effects for number of effective tillers per plant was observed in parent HD 2987 in all the 4 environments. In addition, parent Lok 1 was also the best general combiner in $\mathrm{E}_{1}$ and $\mathrm{E}_{2} \cdot$ The highest positive GCA effects was recorded for parent Raj 4079 in pool, HI 1544 in $E_{1}$, Raj 4079 in $E_{2}$ and Raj 4079 in $E_{4}$ for spike length. None of the parent had significantly positive GCA effects $E_{3}$. For flag leaf area, parent $\mathrm{HI} 1544$ in $\mathrm{E}_{4}$ and GW 366 in remaining environment including pooled was the good general combiner. Parent Raj 4037 in $\mathrm{E}_{1}, \mathrm{E}_{2}$, pooled and parent GW 366 in $\mathrm{E}_{4}$ showed highest GCA effect for 1000-grain weight. The highest GCA effects for harvest index were exhibited by parent GW 366 in $\mathrm{E}_{2}$ and Raj 4037 in $\mathrm{E}_{4}$.

The data on GCA effects of different parents indicated that the effects varied significantly for different characters and in different environments. Based on estimates of GCA effects on pooled basis for various characters, parents HD 2987, Lok 1 and HI 1544 were good general combiners for grain yield in pool. The good general combiners had fixable component of variance like additive and additive $\times$ additive epistasis component; therefore, these parents offer the best possibilities of exploitation for development of improved high yielding lines with heat tolerance in bread wheat. It was further noted that involvement of these parents had resulted into hybrids expressing useful heterosis for various traits.

Sprague and Tatum (1942) reported that the specific combining ability is important parameter for judging and selecting superior cross combinations, which might be exploited through heterosis breeding. The crosses which showed highest significant positive SCA effects for different characters are presented from Tables 4 to 7.

Among the hybrids on pooled basis, Crosses Raj $4037 \times$ HD 2987 showed highest SCA effects in negative direction for days to heading and days to maturity, whereas showed highest SCA effects in positive direction for number of grains per spike. Crosses PBW $175 \times \mathrm{HI} 1544$ followed by GW $366 \times$ Lok 1 and Raj $4079 \times$ Lok 1 had highest SCA effects in negative direction for plant height. Similarly, for number of effective tillers per plant, crosses PBW $175 \times$ HD 2987 followed by Raj4037 × Raj 4079, HD $2932 \times$ HD 2987 showed highest SCA effects. The cross GW $366 \times$ HD 2987, HI $1544 \times$ Lok 1 and PBW $175 \times$ HI 1544 possessed highest positive SCA effects for spike length. For flag leaf area, the highest SCA effects were exhibited by the cross Raj $4037 \times$ PBW 175 followed by HD $2932 \times$ HI 1544, GW $366 \times$ PBW 175 and GW $366 \times$ Lok 1.SCA effects were maximum for 1000-grain weight in the crosses HD $2932 \times$ PBW 175 followed by Raj $4079 \times$ Lok 1 . Cross HD $2932 \times$ Raj 4079 followed by Raj $4037 \times$ HD 2987 had highest SCA effects for biological yield per plant. The highest value of SCA effects for grain yield per plant were recorded in the crosses HI $1544 \times$ HD 2987 followed by HI $1544 \times$ RAJ 4079, PBW $175 \times$ HD 2987. SCA effects were maximum for harvest index in the cross GW $366 \times$ Lok 1 .

The estimates of SCA effects revealed that none of the hybrids was consistently superior for all the traits. The significant SCA effects might be due to the presence of intra or inter allelic interaction and can be easily exploited in cross pollinated crops and in self-pollinated crops where commercial hybrid seed production is possible. However, if its parents are good general combiners the high SCA might be due to accumulation of dominant alleles from both the parents, if so it can be easily exploited in self-pollinated crops by selecting transgressive segregates in segregating generations. 
In the present investigation, parents HD 2987, Lok 1 and HI 1544 were good general combiners for grain yield over different environments. Therefore, these parents offer the best possibilities of exploitation for development of improved high yielding lines with heat tolerance in bread wheat. The cross HI $1544 \times$ HD 2987 was the best specific combiner for grain yield per plant followed by HI $1544 \times$ RAJ 4079, PBW $175 \times$ HD 2987. They produced significant and desirable SCA effects and heterosis for most of the traits studied indicating potential for exploiting hybrid vigor in breeding programme.

\section{Acknowledgements}

The authors express their heartfelt thanks to Department of Science and Technology, Government of India for providing Inspire Fellowship to Ph.D. research work.

\section{References}

Braun HJ, Rajaram S and Ginkel MV 1996. CIMMYT's approach to breeding for wide adaptation. Euphytica 92: $175-183$.

Ceccarelli S 1989. Wide adaptation: How wide. Euphytica 40: 197-205.

DAC \& FW 2016. Directorate of Economics and Statics, Department of agriculture cooperation and farmers welfare.

Griffing B 1956. Concepts of general and specific combining ability in relation to diallel crossing system. Australian Journal of Biological Science 9: 463-93.

Joshi SK, Sharma SN, Singhania DL and Sain RS 2002. Genetic analysis of quantitative and quality traits under varying environmental conditions in bread wheat. Wheat Information Service 95: 5-10.

Panse VC and Sukhatme PV 1985. Statistical methods for agricultural workers. Indian Council of Agricultural Research, New Delhi.

Sharma M, Sohu VS and Mavi GS 2003. Gene action for grain yield and its components under heat stress in bread wheat. Crop Improvement 30: 189-197.

Singh D 1973. Diallel analysis over different environments-I. Indian Journal of Genetics and Plant Breeding 33: $127-136$.

Singh SV and Yadav RK 2011. Combining ability analysis under different locations of U.P. in wheat (Triticum aestivum L.). Bhartiya Krishi Anusandhan Patrika 26: 118-122.

Sprague GF and Tatum LA 1942. General vs specific combining ability in single crosses in corn. J. Amer. Soc. Agron. 34: 923-932. 